\title{
DEVELOPMENT MODEL FOR REMOVAL TOTAL IRON IN “GAMBUT WATER" FOR DRINKING WATER
}

\author{
Sutrisno $^{1}$, Elizabeth Tjahjadarmawan ${ }^{2}$ and Fifi $^{2}$ \\ ${ }^{1}$ Jurusan PMIPA FKIP Universitas Jambi, Kampus UNJA Mendalo Darat Jambi \\ ${ }^{2}$ Senior High School Xaverius 1, Kota Jambi \\ email : alyatriska@telkom.net
}

\begin{abstract}
This research is focused on characterization of activated carbon from solid waste CPO industries and applying for treatments of gambut water for iron removal in aqueous media. Key parameters in the present study include TSS, DO, $\mathrm{pH}$ and total phenol is also determinated. Methods of sampling and analytical techniques for measuring key parameters are by using extended method. The small model has been developed by combining of the composting and adsorption technology. The coagulant material such as filter alum, soda caustic, and calcium hypochlorite in any ratios are varied and the optimum condition is achieved. The activated carbon is used as adsorbent by using column model. The overall results show that after coagulation and adsorption processes the total iron, TSS, DO and $\mathrm{pH}$ are under threshold levels (Indonesian Regulation) and suitable for drinking water meanwhile other parameters are still uncovered in this investigation. Tentatively, it can be concluded that the proposed gambit water design has achieved the optimum condition. A further study on the improvement of the treatment design and service time for adsorption process is still in progress.
\end{abstract}

Keywords : total iron, gambut water, activated carbon, combining model.

\section{REFERENCES}

1. Sutrisno., Sonya, P., 2006, Extended Method for Determinating of Phenol in Gambut Water, The Next Step of Nobel Prize in Chemistry.

2. Anonim, 1995, Instalasi Pengolahan Air Gambut untuk Penyediaan Air Bersih, Badan Litbang Pusat Penelitian dan Pengembangan Sumber daya Air, Bandung.

3. Anonim, 1999, Instalasi Pengolahan Air sangat Sederhana, Badan Litbang Pusat Penelitian dan Pengembangan Sumber daya Air, Bandung.

4. Anonim, 2000, Model Pengolahan Air Gambut dengan Menggunakan Sinar UV di Lampung, Lampung.

5. Nurmala dan Hartoyo, 1988 Pemanfaatan Cangkang Sawit sebagai bahan Penyerap Limbah Cair Kayu Lapis, Journal Lingkungan, Indonesia.
6. Ashyar dan Sugiarto, 1997, Reaktivasi Bahan Penyerap dari Kokas Minyak Bumi untuk Limbah Organik, Skripsi (tdk dipublikasikan).

7. Sutrisno, Arrigan, D. W. M., Baugh, P. J., 2004, Determination and Characterization of Iron in aqueous solution and gas phase, Anal. Chem., 2: 247.

8. Sutrisno, 2003, Development Model of Gambut Water in Jambi Province, Bapedalda, Jambi.

14. Goyal, M., Rattan, V.K., Aggarwal, D., Bansal, R.C., 2001, Removal of copper from aqueous solutions by adsorption on activated carbons, Colloids and Surfaces A: Physicochemical and Engineering Aspects, 190(3): 229 - 238.

15. Klein, D. A., and Thayer, J. S., 1995, Interactions between soil microbial Community Organometallic Compounds, Soil Biochemistry, Vol. 6, NY.

17. Anonim, Introduction to Water Quality Analyses Vol. 4, American Water Works 
Association 666 w. quincy ave., Denver, Colorado 80235.

18. Kusnaedi, 2000, Mengolah Air Gambut dan Air Kotor Untuk Air Minum, Penerbit Penebar Swadaya, Anggota IKAPI, Jakarta.

19. Pandia, S., Husin, A., dan Masyitnah, H., 1996, Kimia Lingkungan, PP-PSL, Jakarta.

20. Alaerts, G., dan Santika, S., 1984, Metoda Penelitian Air, Usaha Nasional, Surabaya.

21. Asyar, R., 2004, Determination of Phenol and Nitro-Phenol using re-activated material, $J$. of Environmental Chem., Vol 3(142).

22. Sutrisno., Arrigan, D.W.M., 1997, Determination of Iron By UV-Vis Spectrophotometry after Extraction with N-Phenil N-Benzoyl Hydroxylamine,
XXX Colloquium Spectroscopicum Internationale, XXX CSI 1997, Melbourne.

23. Wiebner A., 1998, et.al/colds Surfaces A: Physicochem.Eng.Aspect, 139: 91-97.

24. Mohan, D.S., 2001, Chander/colloids and surfaces A: Physicochem.Eng.Aspect, 177: 183-196.

25. www.rumahkayu.com/wateraimtop/tipsdan trik.html

26. Laselo, K., et al., 1998, Colloids surfaces A: Physicochem.Eng.Aspect, 138: 29-37.

27. Brennan, J.K., et al., 2001, Colloids and sufaces A: Physicohem. Eng. Aspect, 187-188: 539-568.

28. Day, C., 2001, Colloids and Surfaces A: Physicochem. Eng. Aspect, 187-188: 187206. 